\title{
IAMJ
}

INTERNATIONAL

AYURVEDIC

MEDICAL JOURNAL

Review Article

ISSN: 2320-5091

Impact Factor: 6.719

\section{COMPARATIVE STUDY OF FUNCTION OF SKIN}

\section{Vrushali S. Gayakwad}

Professor of Kriya Sharir Dept, Bhimashankar Ayurved College, Wadgaon Kashimbeg (Walungwadi), Ambegaon, Pune, Maharashtra, India

Corresponding Author: vrushaligayakwad@gmail.com

\section{https://doi.org/10.46607/iamj2708122020}

(Published online: December 2020)

Open Access

(C) International Ayurvedic Medical Journal, India 2020

Article Received: 26/11/2020 - Peer Reviewed: 28/11/2020 - Accepted for Publication: 30/11/2020

\section{Check for updates}

\section{ABSTRACT}

In Ayurvedic compendia, the Twacha is explained as Updhatu of Mamsa Dhatu. We go through all aspect regarding Twacha in Ayurveda \& try to correlate the concept of Twacha with modern concept of skin.

In Ayurvedic compendia a skin is called as "Twacha". Its reference comes as Updhatu of Mamsadhatu. The Ayurvedic point of view regarding Twacha, includes Nirukti, Synonyms, Formation, Layers, Updhatu, Moolastathna and Functional Aspect. Nirukti of Twack means the substance which act as cover. Synonyms for Twak are Charma, Valka etc. According to Sushrut Samhita Twak is formed during fetal life in growing embryo just like layers of cream forms on boiling milk. The skin is often classified as the largest organ of the body and it is one that all surgeons will operate on or through. It is therefore vital that the students understand the layers of the skin and the structures that are found within these layers. The skin can be injured in a number of situations including burns and various diseases. It is important to understand how these injuries can affect the physiological function of the skin. The present article deals with comparative study of functions of skin as per modern health science and Ayurvedic textual references.

Keywords: Twacha, Updhatu, Mamsa Dhatu, Sparshanendriya, twak. 


\section{INTRODUCTION}

The exact meaning of word is called 'Nirukti'. In Amarkosh the Nirukti of Twack means the substance which act as cover or closing up or hiding the things or concealment of the things, as we see the skin covers whole body externally. Synonyms for Twack are Charma, Valka, Valkal' Sparshni, Chedini. These synonyms are given on the basis of various functions of Twack for e.g. Sparshni as it is site of Sparshanendriya. According to Sushrut Samhita there are layers of cream on boiling milk in that same way the skin is formed first during fetal life in growing embryo. There is difference of opinion regarding the no. of Twak layers. Sushrut has explained total 7 layers where as Charak has explained 6 layers of Twak \& the layers are basically related with diseases of Twak. In both Compendia's they explained the various diseases in each layer of Twak. In addition to diseases Sushrut has explained the width of each layer in unit of 'Brihi. In these slides we see the various diseases of Twak. In modern science of medicine, the skin is explained as 'Integumentary system'. Integument means the external covering of body. It is a large organ if about 2 square meters \& weight $4.5-5 \mathrm{~kg}$, about $16 \%$ of total body weight. It includes all structures related to skin. It consists of two parts. The superficial thinner portion, which is composed of epithelial tissue, is the Epidermis. The deeper, thicker connective tissue portion is the Dermis. Deep to the dermis, but not part of skin is subcutaneous layer which is also called as 'Hypodermis', this attaches to the underlying fascia which is the connective tissue around muscle $\&$ bone. The hypodermis layer serves as a storage depot for fat $\&$ contain large on. Of blood vassals that supply the skin.

The epidermis contains 4 principal types of cells.

1. Keratinocytes - hornlike cells arranged in 4 or 5 layers \& produce the keratin protein which protects the skin \& underlying tissues from heat, microbes $\&$ chemicals.

2. Melanocytes - develop from the ectoderm of developing embryo \& produce the pigment melanin which protects damage from UV rays

3. Langerhans - arise from red bone marrow \& migrate to the epidermis. They participate in immune response against5 microbe $\&$ and are easily damaged by UV rays.

4. Markel cells - they located deepest in the layer of epidermis, where they contact the flattened process of a sensory neuron called Markel disc \& they detect touch sensation. Epidermis is composed of 4 to 5 layers of skin. In most of region it is 4 layers thick $\&$ in the areas like palms, sole where there is more friction it is 5 layers thick.

5. Stratum basale - it is the deepest layer. It contains keratinocytes \& stem cells that will undergo cell division to produce new cells.

6. Stratum spinosum - it is superficial to basale. It is 8 to 10 layer thick \& provides both strength \& flexibility to skin. It also contains Langerhans \& melanocytes cells.

7. Stratum granulosum - it is about middle of epidermis. Consist of 3 to 5 layers of flattened keratinocytes that undergo apoptosis. It contains lamellar granules, which release a lipid rich secretion. This secretion acts as water repellent sealant, retarding loss \& entry of water \& foreign materials.

8. Stratum Lucidum - it presents in thick areas of skin like palms, soles. It consists of dead keratinocytes $\&$ thickened plasma membrane.

9. Stratum Corneum - consist of 25 to 30 layers of dead keratinocytes, which shed \& replaced continuously from deeper strata. Its multiple layers of dead cells also help to protect deeper layers from injury \& microbial invasion.

Dermis - it is deeper part of skin. It contains collagen $\&$ elastic fibres, fibroblasts, some macrophages, blood vessels, nerves, glands $\&$ hair follicles. The dermis can be divided in to 2 layers. Papillary Region. It consists of areolar connective tissue with thin collagen $\&$ fine elastic fibbers, contains dermal ridges that house capillaries, Meissner corpuscles, \& free nerve endings.

Reticular Region - consist of dense irregular connective tissue with bundles of thick collagen \& some coarse elastic fibres. A Space between fibbers contains some adipose cells, hair follicles, nerves, sebaceous glands \& sudoriferous glands. From above all information we can compare the layers of skin like. The 
Udaka Dhara that holds water can be compare with epidermis as there is a functional similarity between both. The second layer i.e. Asrigdhara which holds blood can be compare dermis again there is a functional similarity between both. Now we see the functions of Twacha \& comparative function of skin.

\section{DISCUSSION}

Twak-Sparshendriya \& Cutaneous sensations- Twacha is one of Jnyanendriya called as 'Sparshanendriya'. The sense organ that perceives touch. The two Sparshavaha Dhamanis and their branches are spread in the skin to conduct touch from skin to mind. Sparshanendriya occupies mind also \& hence mind can experience favourable, unfavourable conditions (Sukha, Dukha). Due to conduction of Sparshanendriya, subtle (Sukshama) mind can occupy whole body. This similar function of skin is stated as cutaneous sensation including tactile, thermal \& other sensations like pain etc. Ushama Niyaman \& Thermoregulation of skin- As Twak is site for Sweda (sweat) excretion, which is one of three malas. Kleda Viddriti or holding some moisture in the skin is the function of Sweda. Sweda is also site for Pitta \& hence one of function of Sweda is to controls hotness of Pitta by alternating sweat formation. Muscle activity contributes to $80 \%$ heat production in body that heat produced is regulated by Twak. Similar function of thermoregulation is appearing in the skin in two ways.

a) By liberating sweat at its surface- High temp. or heat produced increases sweat production, which helps to lower body temp. When temp. is low sweating is decreased, which help to conserve heat.

b) By adjusting the blood flow in the dermis. - In response to high temp. or heat production, the blood vessel in dermis dilate, which increases more heat loss from body. When temp. is low blood vessels in dermis constrict, which reduces heat loss from body. Blood Reservoir - Dhamnis Moola Sthana - In Sushrut Samhita Dhamins are also explained as Moolasthana of Mamsavaha Srotas. According to Ayurvedic compendia the Varnaprasad (i.e. maintenance of skin color) is the function of Raktadhatu \& it is examined on skin. As cheerful complexion is symptom of pure
Raktadhatu. Similarly, skin is act as blood reservoir as the dermis is a house of extensive network of blood vessel. It carries 8 to $10 \%$ of blood flow in resting adult. Lepan \& Protection \& Twaksarata - The skin provides protection to the body in various ways. It protects underlying tissues from microbes, abrasion, heat \& chemicals. It stops invasion of microbes. It inhibits evaporation of water \& guard against dehydration. It inhibits evaporation of water $\&$ it also retard entry of during showers or swims. The sebum keeps skin \& hair soft, moist $\&$ avoids drying out. The pigment melanin helps shield against damage effects of UV light. As explained by Charaka Twak covers the body externally \& protects the body. The function is carried out similar to skin. Twaksarata - In compendia's during elaboration of Dhatusarata, Rasasarata is also called Twaksarata. The skin of Rasasarata is soft, smooth, Loma's (hair on skin) are fine, sparse \& deeply rooted. As we has seen priviously the skin is site for Sweda excretions. It maintains soft texture of skin \& hair. Bhrajaka pitta \& Excretion \& Absorption- The Twacha is site for Bhrajaka Pitta which is one of the sub types of Pitta. The Pitta Dosha basically related to the metabolic processes of body. Hence as it is the sub type of Pitta it digests various application on Twak. Due to the biotransformation of this Pitta skin got lustre. Sweda excreted from skin carried out Kleda (Kleda Vahan). Kleda also means waste products formed during cellular metabolism. Excretion \& Absorption - Sweat is the vehicle for excretion of small amount of salt, carbon dioxide, ammonia, urea. The absorption of fat-soluble vitamins like A, D, E, K, certain drug, gases like oxygen $\&$ carbon dioxide. Since topical ointments are easily move into skin. Synthesis of vitamin D - Precursor molecule of vitamin D is activated in skin by UV rays in sunlight. Then this activated molecule is modified by liver $\&$ kidney into final form of vitamin D.

\section{CONCLUSION}

From above all references that the function of skin is near about similar to the function of Twacha explained in Ayurvedic Compendia's. 


\section{REFERENCES}

1. Chakrapanidatta Virachita Charak Samhita Sharirsthan, edited by Yadavji Trikamji Acharya, Chaukhambha Publication, Varanasi, fourth edition, 1994, Sharirsthan, Verse no 7/4.page no 337.

2. Chakrapanidatta Virachita Charak Samhita Sharirsthan, edited by Yadavji Trikamji Acharya, Chaukhambha Publication, Varanasi, fourth edition, 1994, Sutra Sathan, Verse no 8/10.page no 56.

3. Chakrapanidatta Virachita Charak Samhita Sharirsthan, edited by Yadavji Trikamji Acharya, Chaukhambha Publication, Varanasi, fourth edition, 1994, Sutra Sathan, Verse no 11/38.page no 75.

4. Chakrapanidatta Virachita Charak Samhita Sharirsthan, edited by Yadavji Trikamji Acharya, Chaukhambha Publication,Varanasi, fourth edition, 1994, viman sathan,Verse no 8/103.page no 278.

5. Chakrapanidatta Virachita Charak Samhita Sharirsthan, edited by Yadavji Trikamji Acharya, Chaukhambha Publication, Varanasi, fourth edition, 1994, chiktsa sathan, Verse no 15/17.page no 514.

6. Susruta Samhita, Nibandhasangraha Commentary, Sharirsthan, of Shri Dalhanacharya, edited by Yadavji Trikamji Acharya, Chaukhambha Publication, Varanasi, Sharir sthan Verse no 4/4, page no 355.

7. Susruta Samhita, Nibandhasangraha Commentary, Sharirsthan, of Shri Dalhanacharya, edited by Yadavji Trikamji Acharya, Chaukhambha Publication, Varanasi, Sutra Sthan Verse no 35/16, page no 152.

8. Astahgahrdayam, vagbhata, Chaukhambha orientalia, Varanasi, edition tenth, 2014, Sutra Sthana, Verse no 12/1 page no 192.

9. Susruta Samhita, Sharir Sthan, Dr. Bhaskar Govind Ghanekar, reprint Jan 2019, Meharehand Lachhmandas Publications, New Delhi, Verse no 4/3 page no 104 to 107.

10. K. Sembulingam Essentials of Medical Physiology, $7^{\text {th }}$ edition, Jaypee Brothers Medical Publication (P) LTd. New Delhi section no 5 Renal Physiology and Skin, page no. 363 to 358 .

11. Textbook of Medical Physiology, Guyton \& Hall, $13^{\text {th }}$ edition, Elsevier Publication, Sriniwaspuri, New Delhi, chapter 73 page no $133,881,886$.

12. Principles of Anatomy \& Physiolog, Tortora \& Grabowski, $15^{\text {th }}$ edition, John Wiley \& sons, Inc, New York, chapter 5 page no 127 to 144 .
13. Inderbir Singh's textbook of Human histology, $9^{\text {th }}$ edition, Jaypee Brother Medical Publishers, New Delhi| London| Panama, Chapter 11 page no 139 to 150.

14. Comprehensive Textbook of Medical Physiology, $2^{\text {nd }}$ edition, Vol 2, Jaypee Brother Medical Publishers, New Delhi| London, chapter 176 page no 1291 to 1294.

15. Gray's Anatomy for students, edition $4^{\text {th, }}$ vol 1 , Elsevier, Relx India pvt. Ltd. New Delhi, chapter 1, The Body, page no 29 to 30 .

\section{Source of Support: Nil Conflict of Interest: None Declared}

How to cite this URL: Vrushali S. Gayakwad: Comparative Study of Function of Skin. International Ayurvedic Medical Journal \{online\} 2020 \{cited December, 2020\} Available from: http://www.iamj.in/posts/images/upload/5364 5367.pdf 